\title{
Pelatihan Internet of Things Untuk Guru SMA Tanwir Surabaya Dengan Menerapkan Aturan Social Distancing Pada SMA Tanwir
}

\author{
Norma Ningsih, Teguh Sutanto, Harianto \\ Universitas Dinamika, Indonesia \\ norma@dinamika.ac.id, teguh@dinamika.ac.id, hari@dinamika.ac.id
}

\begin{abstract}
ABSTRAK
SMA Tanwir berdiri sejak tahun 2003 dan berlokasi di JL. SEKOLAHAN NO.41, Asemrowo, Kec. Asemrowo, Kota Surabaya Provinsi Jawa Timur. Sekolah SMA tanwir merupakan salah satu sekolah swasta yang ada di kota Surabaya. Saat ini memiliki siswa laki-laki sebanyak 41 orang dan siswi perempuan sebanyak 40 orang dengan didampingi 7 orang guru sebagai pengampu mata kuliah. SMA Tanwir telah menerapkan teknologi informasi dan komunikasi (TIK) dalam proses pembelajaran. Terdapat kelas vokasi yang diadakan setiap hari jumat yang mengandung muatan pemrograman computer. Untuk kelas vokasi program computer saat ini hanya terbatas pada desain yang menggunakan corel dan photoshop. Di masa yang akan datang potensi market place dari Internet of Things sendiri akan semakin besar. dimana pemerintah telah mencanangkan program Making Indonesia 4.0 yang salah satu kompenennya ialah IoT. Pemerintah Indonesia menargetkan sebanyak 400.000 sensor yang terpasang di Indoesia untuk 440 kota yang harus rampung di 2022 (Supangkat, 2019). Dengan melihat latar belakang dan peluang yang telah disampaikan diatas maka pengusul menawarkan pelatihan pemrograman dan Internet of Things bagi para guru di SMA Tanwir agar guru siap untuk mengantarkan dan mendampingi para siswa menuju era revolusi 4.0. Program ini diharapkan dapat meningkatkan pengetahuan dan ketrampilan guru terkait dengan pemrograman dan penerapan Internet of Things dalam kehidupan sehari-hari sehingga dapat mentransformasikan pengetahuan yang dimilki kepada para siswa. hasil dari pengabdian masyarakat ini adalah modul elektronika dengan pemanfaatan LED dan sensor. serta Evaluasi Pelatihan Pemrograman dan IoT menggunakan kuisioner untuk para guru. dengan adanya pelatihan ini dapat meningkatkan kemampuan para guru terutama dalam bidang teknologi.
\end{abstract}

Keyword : Pengenalan, Pemrograman, IoT

\section{PENDAHULUAN}

SMA Tanwir berdiri sejak tahun 2003 dan berlokasi di JL. SEKOLAHAN NO.41, Asemrowo, Kec. Asemrowo, Kota Surabaya Provinsi Jawa Timur. Visi yang ada pada SMA Tanwir adalah (1) Membekali ilmu pengetahuan dan keterampilan yang cukup dan mandiri. (2) Membina Akhlakul karimah dan kepribadian yang tangguh, cerdas, terampil dan trengginas. Untuk mencapai visi tersebut SMA Tanwir berupaya dalam memadukan kurikulum nasional sehingga diharapkan dapat menghasilkan siswa yang kompeten dalam bidang ilmu pengetahuan dan menjadikan siswa yang memiliki akhlakul karimah. Dalam proses pembelajaran sekolah SMA Tanwir memiliki guru yang professional yang berasal dari lulusan S1 dan S2. Selain itu sekolah SMA Tanwir menawarkan pembelajaran kewirausahaan, mentoring agama islam serta pembelajaran berbasis IT yang didukung dengan adanya akses internet gratis untuk guru, karyawan dan siswa. Beberapa fasilitas yang diberikan sekolah untuk para siswanya adalah lapangan olahraga, laboratorium, Masjid, Tempat parker, perpustakaan, ruang multimedia dan ruang komputer. Lingkungan sekolah SMA Tanwir dapat dilihat pada gambar 1. Pada SMA Tanwir terdapat kelas vokasi yang salah satunya adalah kelas program computer. Dengan 
adanya pelatihan ini diharapkan dapat menambah kemampuan para guru di SMA Tanwir mengenai Programming dan IoT, sehingga kedepannya bisa dijadikan salah satu mata pelajaran baru khususnya pada kelas vokasi yang dapat diajarkan pada para siswa. yang tentu saja akan memberikan dampak yang baik bagi siswa dengan kemampuan teknologi update yang dimiliki.

\section{Permasalahan Mitra}

Sekolah SMA tanwir merupakan salah satu sekolah swasta yang ada di kota Surabaya. Saat ini memiliki siswa laki-laki sebanyak 41 orang dan siswi perempuan sebanyak 40 orang dengan didampingi 7 orang guru sebagai pengampu mata kuliah.

Pada saat ini sekolah SMA Tanwir sedang proses dalam penyesuaian kurikulum terkait dengan perkembangan teknologi menuju era Revolusi Industry 4.0 dan merdeka belajar yang sempat digagas oleh Kementeri Pendidikan dan Kebudayaan Indonesia saat ini.

Untuk mendukung hal tersebut SMA Tanwir telah menerapkan teknologi informasi dan komunikasi (TIK) dalam proses pembelajaran. Terdapat kelas vokasi yang diadakan setiap hari jumat yang mengandung muatan pemrograman komputer. Kelas vokasi ini merupakan kelas pilihan yang tidak diwajibkan untuk semua siswa, hanya siswa yang berminat untuk menyalurkan bakat dan minat mereka sebagai pengetahuan tambahan diluar mata kuliah wajib. Untuk kelas vokasi program computer saat ini hanya terbatas pada desain yang menggunakan Corel Draw dan Adobe Photoshop.

Pelajaran pemrograman computer sempat diusulkan untuk masuk dalam kurikulum sekolah mulai dari ingkat dasar hingg pendidikan menengah. Hal ini dimaksudkan untuk melatih cara berfikir logis, problem solving dan kretaivitas dari siswa sekolah yang nantinya dibutuhkan untuk semua profesi di era teknologi sekarang. Hal ini dilakukan karena melihat potensi besar dari generasi muda pencipta aplikasi di Indonesia (Rudiantara, 2015). Namun tentu saja peran sangat sangat diperlukan untuk membantu mengarahkan siswa baik dalam penggunaan teknologi maupun membantu menemukan bakat yang dimiliki para siswa. Para guru dituntut memiliki kreatifitas dan inovasi dalam menghadapi perkembangan teknologi sehingga peserta didik dapat dengan maksimal menyerap ilmu dengan mudah dan menyenangkan serta mendapat pondasi agama yang kuat (fahmi, 2020).

Di masa yang akan datang potensi market place dari Internet of Things sendiri akan semakin besar. dimana pemerintah telah mencanangkan program Making Indonesia 4.0 yang salah satu kompenennya ialah IoT. Pemerintah Indonesia menargetkan sebanyak 400.000 sensor yang terpasang di Indoesia untuk 440 kota yang harus rampung di 2022 (Supangkat, 2019). Selain itu menurut Alhafidh (2019) dan Hari Santoso (2018) perkembangan IoT akan terus meningkat dimasa yang akan datang dan hal ini dapat menjadi peluang bisnis yang besar terutama bagi generasi muda. Dengan melihat latar belakang dan peluang yang telah disampaikan diatas maka pengusul menawarkan pelatihan pemrograman dan Internet of Things bagi para guru di SMA Tanwir agar guru siap untuk mengantarkan dan mendampingi para siswa menuju era revolusi 4.0. Program ini diharapkan dapat meningkatkan pengetahuan dan ketrampilan guru terkait dengan pemrograman dan penerapan Internet of Things dalam kehidupan sehari-hari sehingga dapat mentransformasikan pengetahuan yang dimilki kepada para siswa. 
Tabel 1. Prioritas Permasalahan Mitra

\begin{tabular}{|l|l|l|}
\hline Kategori & Uraian & Masalah Mitra \\
\hline IT & Perkembangan Teknologi & $\begin{array}{l}\text { Kurangnya pengetahuan mengenai isu terkini di } \\
\text { bidang Teknologi }\end{array}$ \\
\hline Pembelajaran & $\begin{array}{l}\text { Keragaman Mata Pelajaran } \\
\text { Tambahan }\end{array}$ & $\begin{array}{l}\text { Kurangnya jenis mata Pelajaran yang ditawarkan } \\
\text { oleh sekolah kepada para siswa terutama terkait } \\
\text { teknologi update }\end{array}$ \\
\hline
\end{tabular}

\section{METODE}

Tahapan untuk melakukan program kemitraan masyarakat pada SMA Tanwir dimulai dari menganalisa kebutuhan mitra untuk menemukan masalah dan solusi dari setiap permasalahan dalam upaya peningkatan kemampuan guru SMA Tanwir dalam hal pemrograman dan IoT, seacara detail diuraikan dalam prosedur kerja yang mendukung realisasi kegiatan pelatihan dapat dilihat di Gambar.

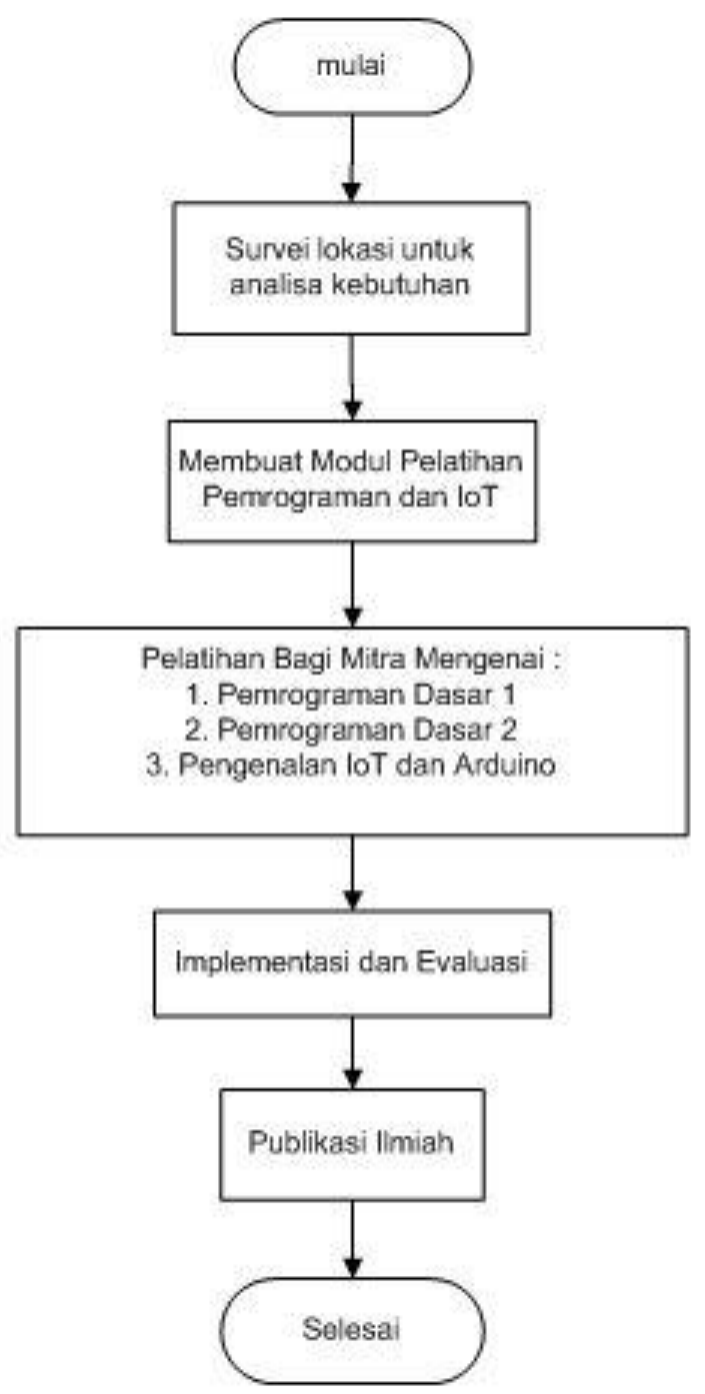

Gambar 1. Prosedur kerja Pelatihan Pemrograman dan IoT 
Pada gambar 1 merupakan gambaran kegiatan yang dilakukan untuk melakukan pengabdian pada sekolah SMA Tanwir Surabaya, berikut adalah uraiannya :

1. Melakukan Survei untuk menganalisa kebutuhan dan permasalahan Mitra

2. Menyusun modul pelatihan yang berisi pemrograman dasar dan penggunaan Arduino untuk penerapan Internet of Things
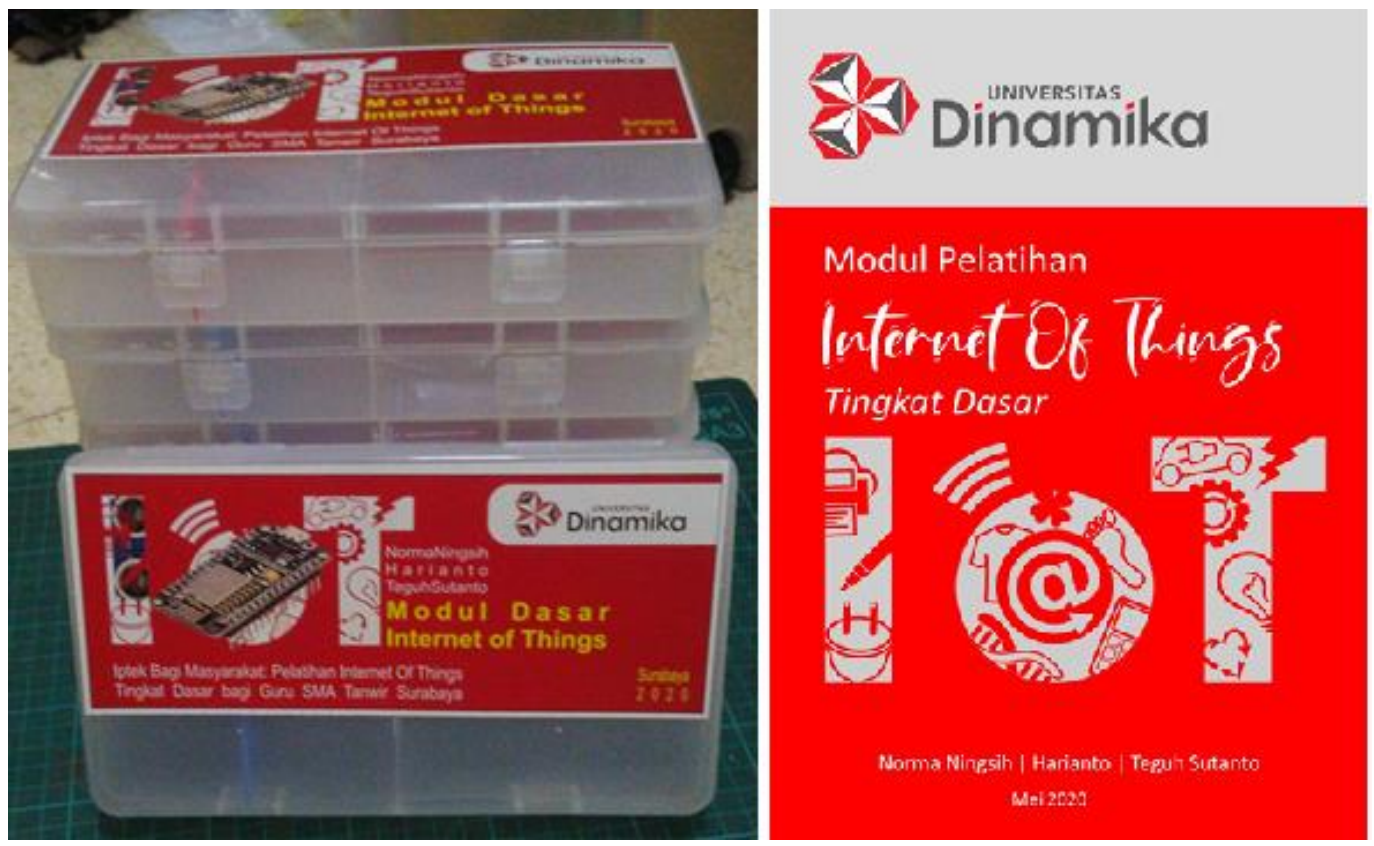

Gambar 2. Modul Pelatihan dan Modul Kits

3. Memberikan Pelatihan kepada guru SMA tanwir. Pelatihan yang diberikan meliputi :

a. Pelatihan Program Dasar 1

Pelatihan ini berisi dasar-dasar pemrograman yang meliputi pengenalan variable dan tipe data

b. Pelatihan Program Dasar 2

Pelatihan ini berisi dasar-dasar pemrograman yang meliputi pengenalan Alur logika berupa percabangan dan perulangan serta fungsi dari void setup() dan void loop()

c. Pengenalan Internet of Things dan Arduino

Pelatihan ini merupakan bentuk pengenalan kepada peserta mengenai konsep dasar Internet of Things dan bagaimana cara untuk menggunakan Arduino sebagai salah satu cara untuk menerapkan internet of things seperti upload program, compile dan running program pada arduino

d. Penggunaan Arduino

Implementasi berbagai studi kasus yang diterapkan pada perangkat Arduino seperti menyalakan LED sederhana, simulasi lampu lintas dll

4. Melakukan Evaluasi dengan menyebar kuisioner dan memberikan pertanyaan terkait materi yang sudah diberikan untuk mengetahui tingkat pemahaman peserta pelatihan 


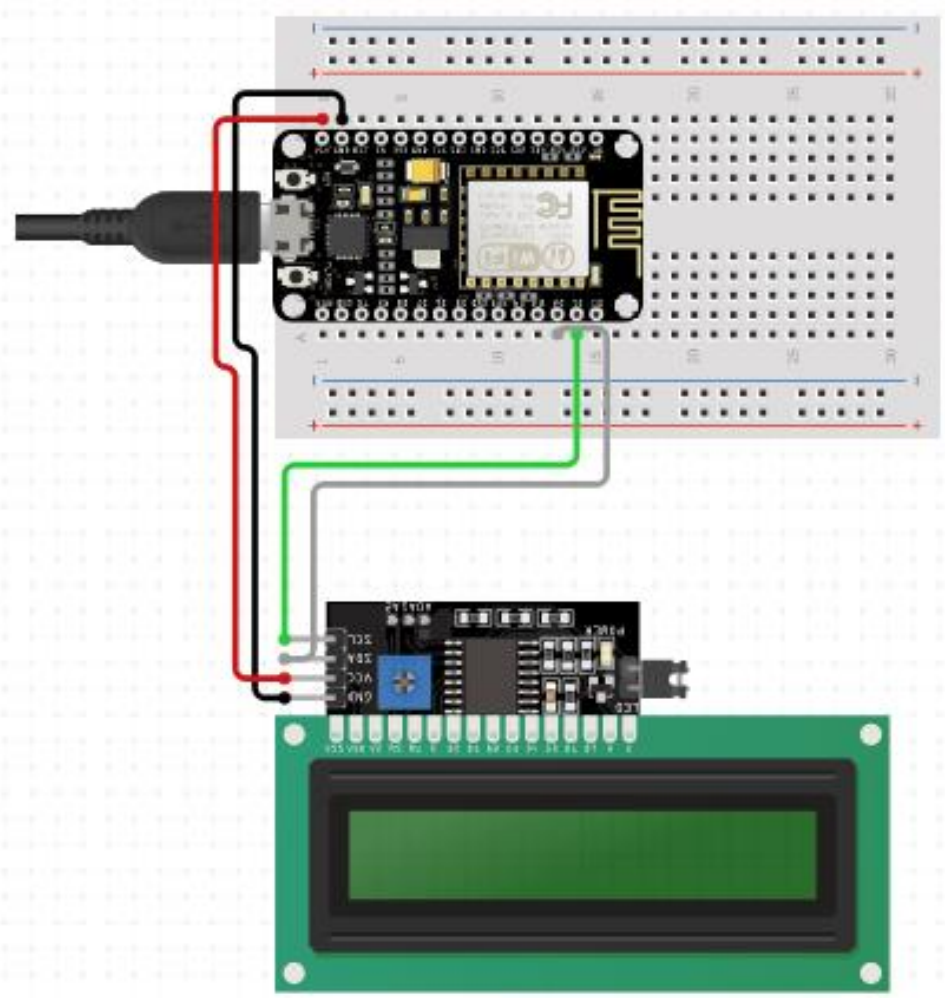

Gambar 3. Rancangan Perangkat

Dalam pelatihan ini menggunakan NodeMCU sebagai microcontroller untuk mensimulasikan perangkat IoT .

\section{HASIL DAN PEMBAHASAN}

\section{Internet of Things}

Karena pelatihan masih dalam masa pandemic maka proses pelatiha dilakukan dengan menerapkan $80 \%$ belajar mandiri melaui modul yang sudah disiapkan dan $20 \%$ pelatihan tatap muka dengan tetap memperhatikan protocol kesehatan pencegahan Virus Covid 19.

Dengan Pelatihan yang telah diberikan untuk para guru di SMA Tanwir Surabaya dapat meningkatkan pengetahuan para guru dalam bidang teknologi terutama pemrograman dan Internet of Thing yang sedang berkembang saat ini dan mengembangkan keilmuan dengan munculnya inovasi baru dalam bidang teknologi.

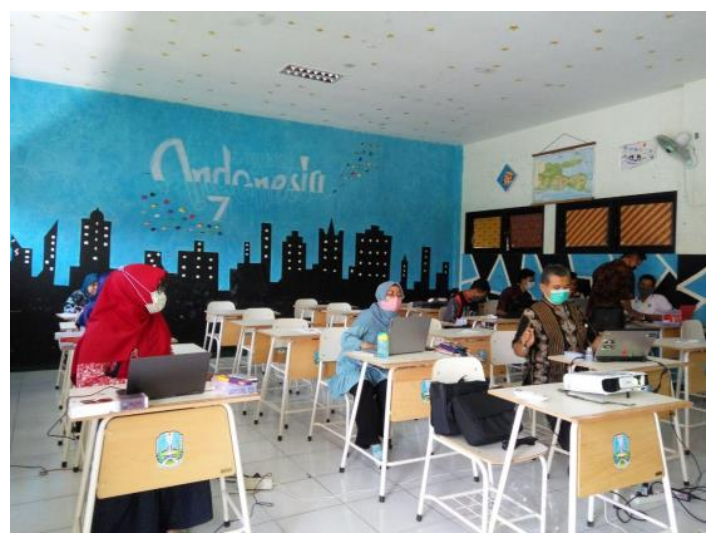

Gambar 4. Peserta Pelatihan 


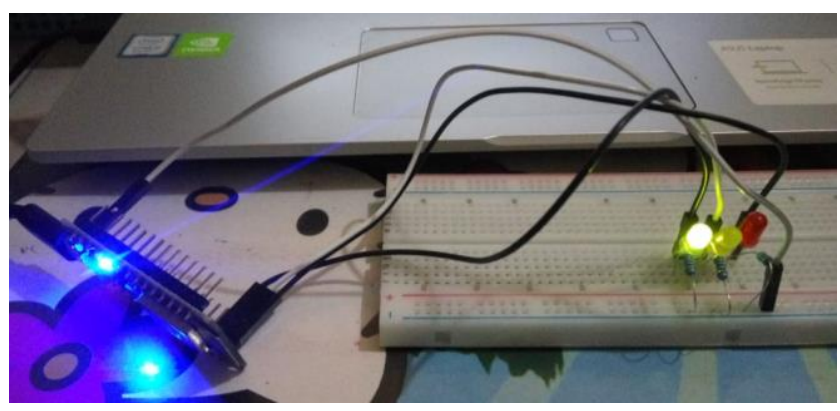

Gambar 5. Rangakain IoT

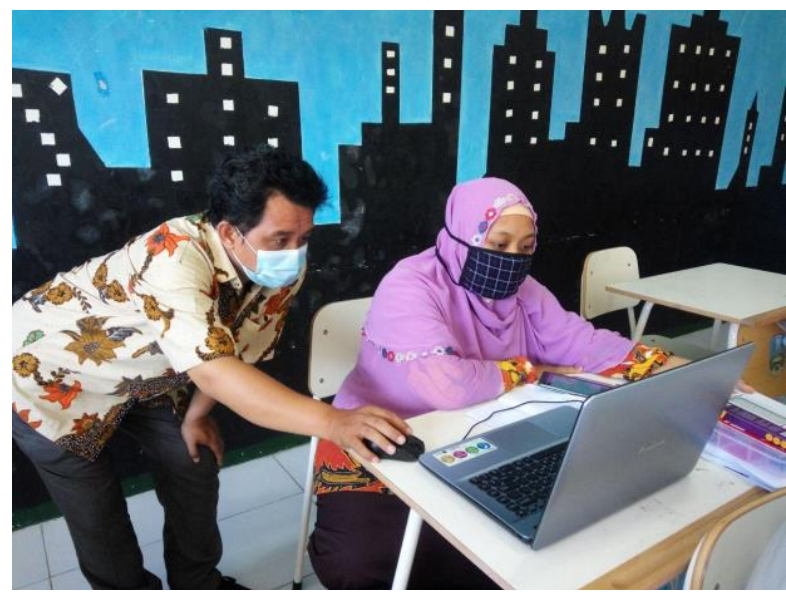

Gambar 6. Penjelasan Materi

Adapun hasil analisis evaluasi kuisioner pelatihan Guru dapat dilihat pada Tabel 5.1.

\section{Bobot Skala Likert :}

1. Sangat Setuju : 4

2. Setuju : 3

3. Tidak Setuju : 2

4. Sangat Tidak Setuju : 1

Tabel 2 Hasil Kuisioner Pelatihan Guru

\begin{tabular}{|l|l|l|l|l|l|l|}
\hline No. & Pertanyaan & SS & S & TS & STS & $\begin{array}{l}\text { Total } \\
\text { Responden }\end{array}$ \\
\hline 1 & $\begin{array}{l}\text { Pelatihan menggunakan IoT ini dapat menambah } \\
\text { wawasan baru bagi Bapak/Ibu Guru. }\end{array}$ & 8 & 4 & 0 & 0 & 12 \\
\hline 2 & $\begin{array}{l}\text { Tim Pelaksana Pelatihan telah menyajikan materi } \\
\text { dengan jelas dan mudah dipahami. }\end{array}$ & 10 & 2 & 0 & 0 & 12 \\
\hline 3 & $\begin{array}{l}\text { Pelayanan fasilitas dan konsumsi pada Pelatihan IoT } \\
\text { sudah memadai }\end{array}$ & 9 & 3 & 0 & 0 & 12 \\
\hline 4 & $\begin{array}{l}\text { Pengetahuan mengenai IoT ini mudah digunakan } \\
\text { oleh Bapak/Guru. }\end{array}$ & 7 & 5 & 0 & 0 & 12 \\
\hline 5 & $\begin{array}{l}\text { Pelatihan ini dapat meningkatkan profesionalisme } \\
\text { dan kompetensi Bapak/Ibu Guru. }\end{array}$ & 10 & 1 & 1 & 0 & 12 \\
\hline 6 & $\begin{array}{l}\text { Perlu diadakan Pelatihan Lanjutan atau dengan topik } \\
\text { yang lain. }\end{array}$ & 9 & 2 & 1 & 0 & 12 \\
\hline 7 & $\begin{array}{l}\text { Setelah kegiatan pelatihan ini saya akan mencoba } \\
\text { menerapkannya kepada murid saya }\end{array}$ & 8 & 2 & 2 & 0 & 12 \\
\hline 8 & $\begin{array}{l}\text { Materi yang diajarkan sesuai dengan kebutuhan } \\
\text { saya }\end{array}$ & 8 & 3 & 1 & 0 & 12 \\
\hline
\end{tabular}




\begin{tabular}{|l|l|l|l|l|l|l|}
\hline No. & Pertanyaan & SS & S & TS & STS & $\begin{array}{l}\text { Total } \\
\text { Responden }\end{array}$ \\
\hline 9 & $\begin{array}{l}\text { Pemateri memiliki kompetensi yang sesuai dengan } \\
\text { materi yang diajarkan }\end{array}$ & 11 & 1 & 0 & 0 & 12 \\
\hline 10 & $\begin{array}{l}\text { Materi yang disampaikan bermanfaat dalam } \\
\text { pekerjaan saya sehari-hari }\end{array}$ & 9 & 3 & 0 & 0 & 12 \\
\hline
\end{tabular}

Tabel 3 Perhitungan Hasil Kuisioner Pelatihan Guru.

\begin{tabular}{|l|l|l|l|l|l|l|l|l|l|}
\hline $\begin{array}{l}\text { No. } \\
\text { P }\end{array}$ & SS & S & $\begin{array}{l}\text { T } \\
\text { S }\end{array}$ & $\begin{array}{l}\text { ST } \\
\text { S }\end{array}$ & $\begin{array}{l}\text { Pembobot } \\
\text { an } \\
(\text { SS x 4) }\end{array}$ & $\begin{array}{l}\text { Pembobot } \\
\text { an } \\
(\mathbf{S} \times \text { 3) }\end{array}$ & $\begin{array}{l}\text { Pembobot } \\
\text { an } \\
(\text { TS x 2) }\end{array}$ & $\begin{array}{l}\text { Pembobot } \\
\text { an } \\
(\text { STS x 1) }\end{array}$ & $\begin{array}{l}\text { Total } \\
\text { Bobot }\end{array}$ \\
\hline P1 & 8 & 4 & 0 & 0 & 32 & 12 & 0 & 0 & 44 \\
\hline P2 & 10 & 2 & 0 & 0 & 40 & 6 & 0 & 0 & 46 \\
\hline P3 & 9 & 3 & 0 & 0 & 36 & 9 & 0 & 0 & 45 \\
\hline P4 & 7 & 5 & 0 & 0 & 28 & 15 & 0 & 0 & 43 \\
\hline P5 & 10 & 1 & 1 & 0 & 40 & 3 & 2 & 0 & 45 \\
\hline P6 & 9 & 2 & 1 & 0 & 36 & 6 & 2 & 0 & 44 \\
\hline P7 & 8 & 2 & 2 & 0 & 32 & 6 & 4 & 0 & 42 \\
\hline P8 & 8 & 3 & 1 & 0 & 32 & 9 & 2 & 0 & 43 \\
\hline P9 & 11 & 1 & 0 & 0 & 44 & 3 & 0 & 0 & 47 \\
\hline P10 & 9 & 3 & 0 & 0 & 36 & 9 & 0 & 0 & 45 \\
\hline
\end{tabular}

Tabel 4 Perhitungan Persentase Akhir

Skor Level Tertinggi $=$ Bobot tertinggi $x$ jumlah responden $=4 \times 12=48$

\begin{tabular}{|c|c|c|c|}
\hline No. & Pertanyaan & $\begin{array}{l}\text { Total } \\
\text { Bobot }\end{array}$ & $\begin{array}{l}\text { Persentase } \\
\text { Akhir } \\
\text { (Total } \\
\text { Bobot/Skor } \\
\text { Level } \\
\text { Tertinggi ) } x \\
100 \%\end{array}$ \\
\hline 1 & $\begin{array}{l}\text { Pelatihan menggunakan IoT ini dapat menambah } \\
\text { wawasan baru bagi Bapak/Ibu Guru. }\end{array}$ & 44 & $91.67 \%$ \\
\hline 2 & $\begin{array}{l}\text { Tim Pelaksana Pelatihan telah menyajikan materi } \\
\text { dengan jelas dan mudah dipahami. }\end{array}$ & 46 & $95.83 \%$ \\
\hline 3 & $\begin{array}{l}\text { Pelayanan fasilitas dan konsumsi pada Pelatihan IoT } \\
\text { sudah memadai }\end{array}$ & 45 & $93.75 \%$ \\
\hline 4 & $\begin{array}{l}\text { Pengetahuan mengenai IoT ini mudah digunakan } \\
\text { oleh Bapak/Guru. }\end{array}$ & 43 & $89.58 \%$ \\
\hline 5 & $\begin{array}{l}\text { Pelatihan ini dapat meningkatkan profesionalisme } \\
\text { dan kompetensi Bapak/Ibu Guru. }\end{array}$ & 45 & $93.75 \%$ \\
\hline 6 & $\begin{array}{l}\text { Perlu diadakan Pelatihan Lanjutan atau dengan topik } \\
\text { yang lain. }\end{array}$ & 44 & $91.67 \%$ \\
\hline 7 & $\begin{array}{l}\text { Setelah kegiatan pelatihan ini saya akan } \\
\text { mencoba menerapkannya kepada murid saya }\end{array}$ & 42 & $87.5 \%$ \\
\hline 8 & Materi yang diajarkan sesuai dengan kebutuhan saya & 43 & $89.58 \%$ \\
\hline 9 & $\begin{array}{l}\text { Pemateri memiliki kompetensi yang sesuai } \\
\text { dengan materi yang diajarkan }\end{array}$ & 47 & $97.92 \%$ \\
\hline
\end{tabular}




\begin{tabular}{|l|l|l|l|}
\hline No. & \multicolumn{1}{|c|}{ Pertanyaan } & $\begin{array}{l}\text { Persentase } \\
\text { Akhir } \\
\text { (Total } \\
\text { Bobot/Skor } \\
\text { Level } \\
\text { Tertinggi ) } \\
\mathbf{1 0 0 \%}\end{array}$ \\
\hline 10 & $\begin{array}{l}\text { Materi yang disampaikan bermanfaat dalam } \\
\text { pekerjaan saya sehari-hari }\end{array}$ & Total \\
Bobot & 45 & $93.75 \%$ \\
\hline
\end{tabular}

Tabel 5 Tabel Kategori Hasil Perhitungan Kuisioner Pelatihan Guru.

\begin{tabular}{|l|l|}
\hline Range Persentase & Kategori Persentase \\
\hline $0 \%-24.99 \%$ & $\begin{array}{l}\text { Sangat Tidak Setuju (Buruk atau Kurang } \\
\text { Sekali) }\end{array}$ \\
\hline $25 \%-49.99 \%$ & Tidak Setuju atau Kurang Baik \\
\hline $50 \%-74.99 \%$ & Setuju, Baik atau Suka \\
\hline $75 \%-100 \%$ & Sangat Setuju (Sangat Baik / Suka Sekali) \\
\hline
\end{tabular}

Berdasarkan hasil perhitungan Kuisioner Pelatihan Guru dapat diambil kesimpulan dengan mengacu pada persentase terbesar dan persentase terkecil yang menyebutkan bahwa $93.75 \%$ Pelatihan ini dapat meningkatkan profesionalisme dan kompetensi Bapak/Ibu Guru. serta 87.5\% menjawab bahwa setelah kegiatan pelatihan ini akan mencoba menerapkan pada kelas vokasi yang ada disekolah.

\section{KESIMPULAN}

Adapun beberapa hal penting yang telah dihasilkan hingga Laporan Akhir ini dibuat adalah sebagai berikut :

1. Kegitan PKM dan Pelatihan telah dilaksanakan sebanyak 2 kali pada bulan September 2020.. Pelatihan dengan bentuk praktek langsung dilaksanakan 2x, yaitu pada tanggal 23 September dengan materi pelatihan pengenalan Internet of Things, Pemrograman Dasar dan Arduino IDE. dan pada tanggal 30 September untuk materi pelatihan Pengenalan NodeMCU dan praktek pembuatan perangkat IoT menggunakan LED dan Sensor.

2. Kegiatan Pelatihan PKM ini telah menghasilkan beberapa luaran dan capaian yang dapat digunakan sebagai pelaporan diantaranya ada pembuatan jurnal dengan judul "Implementasi Pembelajaran Pada Pelatihan Internet of Things untuk Guru SMA Tanwir Surabaya dengan Menerapkan Aturan Social Distancing". proses pengajuan HKI untuk modul pelatihan dengan judul "Modul Pelatihan Internet Of Things Tingkat Dasar". serta perangkat IoT yang telah dihasilkan oleh para guru dengan memanfaatkan LED dan berbagai jenis sensor.

3. hasil perhitungan Kuisioner Pelatihan Guru dapat diambil kesimpulan dengan mengacu pada persentase terbesar dan persentase terkecil yang menyebutkan bahwa 93.75\% Pelatihan ini dapat meningkatkan profesionalisme dan kompetensi Bapak/Ibu Guru. serta 87.5\% menjawab bahwa setelah kegiatan pelatihan ini akan mencoba menerapkan pada kelas vokasi yang ada disekolah. 


\section{UCAPAN TERIMA KASIH}

Penulis Mengucapkan Terima Kasih Kepada :

1. Lembaga Penelitian dan Pengabdian Masyarakat Universitas Dinamika Surabaya atas pendanaan hibah intenal PKM Tahun Anggaran 2020.

2. Pihak Kepala Sekolah dan Guru SMA Tanwir Surabaya beserta staff yang telah berpartisipasi aktif dalam pelatihan ini

\section{DAFTAR PUSTAKA}

Suhono Harso Supangkat. "Menilik Perkembangan IoT di Indonesia". https://www.itb.ac.id/news/read/57158/home/menilik-perkembangan-iot-di-indonesia. Bandung

Abdurrohman Alhafidh. "Bagaimana Perkembangan IoT di Tahun 2020?”. https://www.kompasiana.com/idmetafora/5c91de4e3ba7f707c618c112/bagaimanaperkembangan-iot-di-tahun-2020?page $=$ all

Riga Nurul Iman. "Guru Harus Berinovasi Menghadapi perkembangan Teknologi”. https://www.republika.co.id/berita/pendidikan/eduaction/po2hvq423/guru-tk-harusberinovasi-hadapi-perkembangan-teknologi

pengelola web kemdikbud. "Bakohumas Diskusi Pengembangan Teknologi Pendidikan Melalui Digitalisasi Sekolah". https://www.kemdikbud.go.id/main/blog/2019/10/bakohumas-diskusi-pengembanganteknologi-pendidikan-melalui-digitalisasi-sekolah

Heri Andrianto dan Aan Darmawan. (2015). “Arduino Belajar Cepat dan Pemrograman”. Informatika. Bandung

Hari Santoso (2018), "Monster Arduino 3: Implementasi Internet of Things pada Jaringan GPRS”, Erlangsakti, Malang 